University of St. Thomas, Minnesota

UST Research Online

2014

Creating An Executive Compensation Plan: A Corporate Tax

Planning Case

Janell Blazovich

University of St. Thomas - Minnesota, blaz7322@stthomas.edu

G. Ryan Huston

Arizona State University

Janet M. Huston

Arizona State Univer

Follow this and additional works at: https://ir.stthomas.edu/ocbacctpub

Part of the Accounting Commons

This Article is brought to you for free and open access by the Accounting at UST Research Online. It has been accepted for inclusion in Accounting Faculty Publications by an authorized administrator of UST Research Online. For more information, please contact asle4660@stthomas.edu. 


\title{
Creating an Executive Compensation Plan: A Corporate Tax Planning Case
}

\author{
Janell L. Blazovich, G. Ryan Huston, and Janet M. Huston
}

\begin{abstract}
In this case, the student takes on the role of a compensation committee team member in a publicly traded corporation. The case task is to create a compensation plan for the company's CEO using past data regarding CEO compensation and specific incentives from proxy statements, along with financial statement performance data. To develop a comprehensive plan for the executive, students must incorporate numerous issues and course topics, both tax and nontax, applying them to the particular fact pattern. Pre- and post-case responses from students confirm that this case furthers their understanding of the interplay between corporate tax rules and executive compensation while cultivating critical thinking skills. The case has been used in both graduate tax and graduate accounting courses. To accommodate different teaching philosophies and course emphasis (tax or accounting), three variations of the project are provided.
\end{abstract}

Keywords: executive compensation; corporate taxation; tax planning; earnings management.

\section{CASE A}

$\longrightarrow$ isco Systems is a multinational technology corporation based in San Jose, California that was founded in 1984. Its core business is in the area of networking, including but not limited to routing, wireless networking, and teleconferencing. Cisco believes in the constant evolution of the Internet. They predict a future they call the "Internet of Everything"; a future that provides digital access to information, business processes, and social interactions, all made possible by more internet-capable products.

Following a number of years of service at Wang Industries and IBM, CEO John Chambers joined Cisco in 1991 as a senior vice president. At that time, Cisco Systems was a \$70 million company. When he was appointed CEO in 1995, Cisco was a $\$ 1.2$ billion company. During his tenure as CEO, Cisco experienced meteoric growth to revenue over $\$ 48$ billion in 2013. Beyond revenue growth, John Chambers had many achievements in the areas of corporate social responsibility, philanthropy, and was credited with making Cisco one of the best places to work.

In this case, you are assigned the role of lead member of the compensation committee for Cisco Systems. It is your job to determine the 2014 compensation plan for Cisco's CEO, John Chambers, considering any or all of the following concepts (not limited to this list): ${ }^{1}$

\section{REQUIREMENTS: CASE A}

1. Prepare your compensation plan as follows:

a. Begin by determining certain achievements that you would like for Mr. Chambers to 
make. These could be income targets, expense ratios, stock price targets, or other goals of your choosing.

b. Explain why you selected these specific objectives for him to achieve and how they tie to attributes of the company, industry, or stated objectives provided by the board of directors and/or shareholders.

c. After determining the desired achievements, outline your plan for Mr. Chambers's compensation. There are no specifically right, or wrong, answers for this project; the most important thing is to explain your reasoning for your compensation choices.

d. Explain your reasons for your various plan details with reference to the previous year's (actual) plan, i.e., explaining your rationale for both the changes you propose along with the facets you would keep from the previous year's plan.

2. Discuss the adjustments you would make to your initial compensation plan for the following three independent scenarios:

a. Assume that Cisco chose to increase its dividend from $\$ .68$ per share each year to $\$ 1$ per share.

b. Assume that Cisco's stock price had a 30 percent decline in value due to a macroeconomic shock (similar to $9 / 11$ or the financial crisis) that was not $\mathrm{Mr}$. Chambers's fault. This caused a significant portion of Mr. Chambers's stock options to go underwater, along with significant losses on any stock holdings. This shock also decreased the earnings expectations by a similar 30 percent level, forcing a change in any earnings-related achievements.

c. Assume that two weeks ago, Mr. Chambers announced his retirement effective January $1,2015$.

\section{CASE B}

HealthSouth is a large healthcare corporation focused on inpatient rehabilitative care. Founded in Birmingham, Alabama in 1984, the corporation experienced meteoric growth throughout the early 1990s through a number of mergers and acquisitions. In 2002, a large accounting scandal was uncovered, leading to a Securities and Exchange Commission investigation and a $\$ 1.4$ billion restatement. Over a six-year period beginning in 1996, HealthSouth fraudulently falsified earnings reports to meet analysts' targets and continue revenue growth.

Richard Scrushy, company founder and then-CEO, was an incredibly charismatic executive with grandiose visions for his company, growing revenues to over $\$ 1.5$ billion in the first ten years of operations. He made HealthSouth into the darling of Wall Street by consistently meeting or beating Street expectations. Following the uncovering of the accounting scandal and a circus-like trial, Mr. Scrushy was acquitted of all charges associated with HealthSouth's fraudulent earnings reports.

As the lead member of the compensation committee for HealthSouth, it is your job to determine the 1996 compensation plan for HealthSouth's CEO, Richard Scrushy, considering any or all of the following concepts (not limited to this list): corporate income taxes, dividend policy, stock option plans, pension or retirement benefits, earnings management and other business

Janell L. Blazovich is an Assistant Professor at the University of St. Thomas, and G. Ryan Huston is an Assistant Professor and Janet M. Huston is a Clinical Professor, both at Arizona State University.

The authors greatly appreciate Lisa Gaynor for help with case implementation and financial support from the Deloitte/ American Taxation Association Teaching Innovation Award. 
incentives, and financial reporting considerations. You have been provided with a number of materials explaining the history of HealthSouth, including its accounting scandal. ${ }^{2}$ In your plan, special attention should be paid to any compensation-oriented ideas that might lower the likelihood of such a scandal.

\section{REQUIREMENTS: CASE B}

\section{Directions}

Prepare your compensation plan as follows:

a. Begin by determining certain achievements that you would like for Mr. Scrushy to make. These could be income targets, expense ratios, stock price targets, or other goals of your choosing.

b. Explain why you selected these specific objectives for him to achieve and how they tie to attributes of the company, industry, or stated objectives provided by the board of directors and/or shareholders.

c. After determining the desired achievements, outline your plan for Mr. Scrushy's compensation. There are no specifically right, or wrong, answers for this project; the most important thing is to explain your reasoning for your compensation choices.

d. Explain your reasons for your various plan details with reference to the previous year's (actual) plan, i.e., explaining your rationale for both the changes you propose along with the facets you would keep from the previous year's plan.

\section{CASE C}

You are the lead member of the compensation committee for a multinational corporation of your choice. It is your job to determine next year's compensation plan for your CEO, considering any or all of the following concepts (not limited to this list): corporate income taxes, dividend policy, stock option plans, pension or retirement benefits, earnings management and other business incentives, and financial reporting considerations.

\section{REQUIREMENTS: CASE C}

\section{Directions}

1. Determine the corporation that you will use for your compensation plan. To find the company's proxy statement, you will go to the website: http://www.sec.gov. In the company filings tab, you will type in the company name and then search for the DEF 14a Proxy Statement.

2. Prepare your compensation plan as follows:

a. Begin by determining certain achievements that you would like for your CEO to make. These could be income targets, expense ratios, stock price targets, or other goals of your choosing.

b. Explain why you selected these specific objectives for your CEO to achieve and how they tie to attributes of the company, industry, or stated objectives provided by the board of directors and/or shareholders.

\footnotetext{
1 The following articles and videos may be provided to students at the instructor's discretion: Bloomberg TV (2013); Bort (2013); CBSNews (2011); Endler (2013); Kling (2013); The Economic Times (2013).
} 
c. After determining the desired achievements, outline your plan for your executive's compensation. There are no specifically right, or wrong, answers for this project; the most important thing is to explain your reasoning for your compensation choices.

d. Explain your reasons for your various plan details with reference to the previous year's (actual) plan, i.e., explaining your rationale for both the changes you propose along with the facets you would keep from the previous year's plan.

3. After making your initial compensation plan, explain the changes you would make to your plan under the following three independent scenarios:

a. Assume that your corporation chose to initiate an ordinary, recurring dividend. If your company already pays a recurring dividend, assume that it made a significant increase to the payout.

b. Assume that your company's stock price had a 30 percent decline in value due to a macroeconomic shock (similar to 9/11 or the financial crisis) that was not the CEO's fault. This caused a significant portion of your executive's stock options to go underwater, along with significant losses on any stock holdings. This shock also decreased the earnings expectations by a similar 30 percent level, forcing a change in any earnings-related achievements.

c. Assume that two weeks ago, the company's CEO announced his/her retirement effective January 1, 2015.

\section{REFERENCES}

Birmingham Business Journal. 2009. Crossing the Line: HealthSouth CFO Aaron Beam Speaks Out. Available at: http://www.bizjournals.com/birmingham/stories/2009/10/05/smallb1.html?page=all

Bloomberg TV. 2013. Cisco's Tax Strategy Saves \$7 Billion, Seeks More. Available at: http://www. bloomberg.com/video/71561848-cisco-s-tax-strategy-saves-7-billion-seeks-more.html

Bort, J. 2013. Cisco's John Chambers Has Found a New \$14 Trillion Market. Available at: http://www. businessinsider.com/ciscos-john-chambers-has-found-a-new-14-trillion-market-2013-5

CBSNews. 2011. The New Tax Havens. Available at: http://www.cbsnews.com/videos/the-new-tax-havens$50109660 /$

Consumer News and Business Channel (CNBC). 2009. A Wall Street Wonder Takes a Fall. Available at: http://www.cnbc.com/id/100000081

Endler, M. 2013. Cisco CEO: We' re All in on Internet of Everything. Available at: http://www.informationweek. $\mathrm{com} / \mathrm{software} /$ information-management/cisco-ceo-were-all-in-on-internet-of-everything/d/d-id/1108801?

Kling, M. 2013. Cisco CEO Chambers: U.S. Tax System Is Broken. Available at: http://www.moneynews. com/Economy/Chambers-Cisco-offshore-tax/2013/06/20/id/510970/

Security and Exchange Commission (SEC). 2003. SEC Charges HealthSouth Corp. Richard Scrushy with \$1.4 Billion Accounting Fraud. Available at: https://www.sec.gov/news/press/2003-34.htm

The Economic Times. 2013. Could an Indian Succeed John Chambers at Cisco? Available at: http://articles. economictimes.indiatimes.com/2013-04-18/news/38647374_1_padmasree-warrior-cisco-chambers

The Washington Post. 2004. Timeline of Accounting Scandal at HealthSouth. Available at: http://www. washingtonpost.com/wp-dyn/articles/A24671-2003Oct14.html

USA Today. 2005. Accountant Describes How HealthSouth Fraud Happened. Available at: http:// usatoday30.usatoday.com/money/industries/health/2005-01-28-scrushy_x.htm

2 The following articles and videos may be provided to students at the instructor's discretion: Birmingham Business Journal (2009); CNBC (2009); SEC (2003); The Washington Post (2004); USA Today (2005). 


\section{CASE LEARNING OBJECTIVES AND IMPLEMENTATION GUIDANCE}

\section{Introduction}

In this case, the student takes the role of a member of the compensation committee of a publicly traded corporation. The student's task is to create a compensation plan for the company's CEO using past data regarding CEO compensation and specific incentives from proxy statements, along with financial statement performance data. Students begin by outlining the CEO's annual achievements and the compensation awarded for meeting the objectives. In this process, students must consider the unintended consequences the incentives could cause. For instance, incentive compensation tied to earnings targets could lead to earnings management in a variety of forms, and at the extreme it could lead to outright fraud. Students are expected to consider both the positive outcomes and potential unintended consequences of the incentives their compensation plan creates and include them in their discussion.

\section{Case Learning Objectives}

The case is designed to provide the students with a fundamental understanding and working knowledge of some of the more important concepts, rules, and planning considerations related to producing a compensation plan. Students must integrate both financial and tax accounting issues in the context of managerial incentives and performance.

The Scholes, Wolfson, Erickson, Maydew, and Shevlin (2008) textbook creates a framework for effective tax planning focusing on three specific contexts: (1) the tax implications of a proposed transaction for all parties to the transaction; (2) both explicit taxes (tax dollars paid directly to taxing authorities) and implicit taxes (taxes paid indirectly as a result of lower before-tax rates of return on tax favored investments); and (3) the nontax costs arising from tax planning. ${ }^{3}$

Consistent with the Scholes et al. (2008) framework, this case helps students develop their written communication skills and their critical thinking skills in the context of tax knowledge and tax planning. In all three versions of the case, students observe the importance of financial accounting data and share value on earning incentive-based compensation. While incentive-based compensation generally aligns the interests of manager with shareholders, it also can lead to unintended consequences, like earnings management. All case options allow students to observe the use of stock and option-based compensation methods, along with cash compensation. Students discover that while there are benefits related to incentive compensation, such as aligning the interests of management and shareholders through use of stock and option compensation, stock and option compensation also has negative consequences, such as stock dilution. The specific learning objectives of this case are to improve the students' understanding of the following:

- The various forms of executive compensation;

- The company's objectives in compensation-mix choice;

- The unintended consequences of executive compensation;

- The interplay between tax and nontax issues as they relate to compensation;

- Corporate tax rules;

- The differences between tax planning and tax compliance;

- Various tax planning techniques;

- Earnings management incentives (Case B);

- The interplay between earnings management and executive compensation (Case B);

- Various earnings management techniques (Case B). 


\section{Intended Audience of the Case}

The case has been successfully used in a graduate corporate taxation/Scholes-Wolfson course (Cases $A$ and $C$ ) and a capstone graduate accounting course (Case B). The case is also appropriate and adaptable for other upper-level tax courses (e.g., Tax Research), other upper-level accounting courses, or M.B.A.-level courses. For instance, in a Tax Research course, students could be asked to discuss in much greater detail the deductibility of the various forms of compensation (salary, bonus, stock options, stock appreciation rights, etc.). In an upper-level accounting course, students could be asked to focus on the financial reporting implications of various forms of compensation and how changes in financial reporting for compensation items (e.g., SFAS 123R) have led to changes in compensation plans. Finally, M.B.A. students could focus on the impact of managerial compensation on firm strategy, with a focus on how compensation incentives tie to financial reporting numbers, thus impacting management's choices.

\section{Evidence of Efficacy and Student Feedback}

This case has been administered five times, with student feedback collected during the three most recent administrations. Table 1 presents the results from the Pre/Post Student Questionnaire on the case's learning objectives. Panel A provides student feedback received when students in a graduate corporate taxation/Scholes-Wolfson course completed the Case A version of the case, i.e., Cisco Systems. Data in Panel B come from administering Case B, i.e., HealthSouth, in a capstone graduate accounting course. Panel $\mathrm{C}$ provides data collected after using Case $C$, i.e., students chose the company in a corporate taxation/Scholes-Wolfson course. Both Panels A and C data come from students who were assigned the case as an individual project; Panel B data originate from students assigned the case as a group project. In all three administrations of the case, the pre-case questionnaire was completed before the case was handed out (generally during the first week of the course), and the post-case questionnaire was completed when the case was turned in (generally in the fifteenth week of the course). Student self-assessments increased between the initial and subsequent questionnaire assessment for each learning objective; ${ }^{4}$ thus the case appears to have efficacy in meeting each of the learning objectives. Possibly due to small sample sizes (10 observations in Panel A, and 29 observations in Panels B and C), we are not able to separately identify any effect related to course content (tax or earnings management) or specific instructor. In summary, the results are consistent with the case meeting its stated learning objectives and, as a result of completing the case, students better understand the interplay between compensation and both tax and nontax issues, they are more comfortable with tax planning issues, and they better understand the importance of nontax issues.

Table 2 presents the students' overall assessment of the case; these data come from responses to questions that were asked only on the post-case questionnaire. Panels A and C provide data from students who completed the case individually; Panel B provides data from students who worked in groups to complete the case. Column 3 presents the lower end of the 99 percent confidence interval around the mean; when the lower bound of the confidence interval for a question is greater than the neutral point of 4 , the results are statistically greater than the neutral point, at a 0.01 level. Responses to the first three questions indicate that students believe the case is useful in helping students meet the learning objectives; these data corroborate the pre/post questionnaire results. Student responses to the remaining questions indicate that the level of case difficulty is appropriate for the course and they recommend the case be used again in future semesters. Two of the three

\footnotetext{
${ }^{3}$ It is important to note that the case does not focus on implicit versus explicit taxes, but it does contain issues pertaining to the other two contexts.
} 


\section{TABLE 1}

\section{Student Questionnaire of Learning Objectives Before and After the Case}

Panel A: Case A (Cisco Systems), $\mathbf{n}=10$

\section{Question}

Understanding of the various forms of executive compensation $^{\mathrm{a}}$

Understanding of company's objectives in choosing executive compensation mix

Understanding of the potential for unintended consequences based on executive compensation

Comfortable understanding of corporate tax rules

General understanding of the differences between tax planning and tax compliance

Understanding of interplay between tax and nontax issues relating to compensation

General understanding of tax planning techniques

Panel B: Case B (HealthSouth), $\mathbf{n}=28$

\section{Question}

Understanding of the various forms of executive compensation $^{\text {a }}$

Understanding of company's objectives in choosing executive compensation mix

Understanding of the potential for unintended consequences based on executive compensation

Comfortable understanding of earnings management incentives

General understanding of earnings management techniques

Understanding of interplay between tax and nontax issues relating to compensation

Understanding of the interplay between earnings management and executive compensation

\begin{tabular}{|c|c|c|}
\hline $\begin{array}{c}\text { Week } 1 \\
\text { Mean } \\
\text { (Std. Dev.) }\end{array}$ & $\begin{array}{c}\text { Week } 15 \\
\text { Mean } \\
\text { (Std. Dev.) }\end{array}$ & Difference \\
\hline $\begin{array}{c}4.20 \\
(1.40)\end{array}$ & $\begin{array}{c}5.90 \\
(0.74)\end{array}$ & $1.70 * * *$ \\
\hline 4.60 & 5.80 & $1.20 * *$ \\
\hline (1.43) & (0.79) & \\
\hline 4.90 & 5.80 & 0.90 \\
\hline (1.52) & (1.23) & \\
\hline $\begin{array}{c}4.40 \\
(0.97)\end{array}$ & $\begin{array}{c}5.10 \\
(0.57)\end{array}$ & $0.70^{*}$ \\
\hline 4.80 & 5.00 & 0.20 \\
\hline$(0.63)$ & (0.94) & \\
\hline 4.60 & 5.60 & $1.0^{* *}$ \\
\hline (1.17) & $(0.97)$ & \\
\hline $\begin{array}{c}4.20 \\
(1.62)\end{array}$ & $\begin{array}{c}5.40 \\
(0.70)\end{array}$ & $1.2 * *$ \\
\hline
\end{tabular}

Week 1

Mean

Week 15

Mean

(Std. Dev.)

5.25

(1.04)

(Std. Dev.) Difference

5.14

(1.24)

5.86

$(0.80)$

5.75

$0.61 * *$

$0.61 * *$

$(0.84)$

5.25

(1.11)

6.00

$0.75^{* * *}$

(0.94)

5.46

(1.13)

5.93

(0.66)

5.50

(1.04)

6.11

(0.69)

4.29

4.89

$0.46^{*}$

$0.61 * *$

0.60 *

(1.31)

(0.90)

5.14

5.89

$0.75^{* * *}$

(1.18)

(0.92)

(continued on next page) 


\section{TABLE 1 (continued)}

table1-03b_cont2

\section{Panel C: Case C (Students' Choice), $\mathbf{n}=\mathbf{2 9}$}

\begin{tabular}{|c|c|c|c|}
\hline Question & $\begin{array}{c}\text { Week } 1 \\
\text { Mean } \\
\text { (Std. Dev.) }\end{array}$ & $\begin{array}{c}\text { Week } 15 \\
\text { Mean } \\
\text { (Std. Dev.) }\end{array}$ & Difference \\
\hline Understanding of the various forms of executive compensation ${ }^{a}$ & $\begin{array}{c}4.23 \\
(1.28)\end{array}$ & $\begin{array}{c}5.82 \\
(1.10)\end{array}$ & $1.59^{* * *}$ \\
\hline $\begin{array}{l}\text { Understanding of company's objectives in choosing executive } \\
\text { compensation mix }\end{array}$ & $\begin{array}{r}4.03 \\
(1.45)\end{array}$ & $\begin{array}{c}5.79 \\
(1.01)\end{array}$ & $1.76^{* * * *}$ \\
\hline $\begin{array}{l}\text { Understanding of the potential for unintended consequences } \\
\text { based on executive compensation }\end{array}$ & $\begin{array}{l}3.94 \\
(1.31)\end{array}$ & $\begin{array}{l}5.62 \\
(0.91)\end{array}$ & $1.68 * * *$ \\
\hline Comfortable understanding of corporate tax rules & $\begin{array}{c}4.48 \\
(1.36)\end{array}$ & $\begin{array}{c}5.38 \\
(0.82)\end{array}$ & $0.90 * * *$ \\
\hline $\begin{array}{l}\text { General understanding of the differences between tax planning } \\
\text { and tax compliance }\end{array}$ & $\begin{array}{l}5.03 \\
(1.33)\end{array}$ & $\begin{array}{c}5.72 \\
(0.84)\end{array}$ & $0.69 * * *$ \\
\hline $\begin{array}{l}\text { Understanding of interplay between tax and nontax issues } \\
\text { relating to compensation }\end{array}$ & $\begin{array}{l}4.22 \\
(1.33)\end{array}$ & $\begin{array}{l}5.90 \\
(0.90)\end{array}$ & $1.67 * * *$ \\
\hline General understanding of tax planning techniques & $\begin{array}{c}3.64 \\
(1.28)\end{array}$ & $\begin{array}{c}5.48 \\
(0.91)\end{array}$ & $1.84 * * *$ \\
\hline
\end{tabular}

*,**,*** Significant at the $0.10,0.05,0.01$ levels, respectively.

classes of students surveyed felt the case helped them prepare for their future careers. ${ }^{5}$ Students felt they had access to the necessary resources. Overall the students agreed that the case helped them pull together class concepts, thus enabling them to see the bigger picture.

In the post-case questionnaire students were asked to provide written feedback on both the strengths of the case and the areas in which the case could be improved. Comments received were more positive than negative. The comments confirm that the case integrated many of the course topics and required they think critically about a number of issues simultaneously. Student comments support the use of a "real company" case (regardless of which case used) as a way to deepen their knowledge of course topics. Comments suggesting changes or improvements to the case generally center on the student's preference for more case structure.

Below is a sample of positive comments related to the case:

- "The case was very challenging but forced me to see the big picture and bring all the concepts together."

- "It tied together the various concepts learned in the course and gave the textbook concepts a "real-life' feel."

- "The case really helped me to see the tax theory applied in the real world and see how tax theory interacts with nontax issues." 


\section{TABLE 2}

\section{Student Assessment of Case}

Panel A: Case A (Cisco Systems), $\mathbf{n}=10$

Question

The case offered an effective way to learn tax and compensation planning concepts ${ }^{\mathrm{a}}$

The case illustrated the interplay between tax and nontax issues

After the case, I better understand the importance of nontax issues in compensation planning

The level of difficulty in the case is appropriate for this course

I would recommend the use of this case in future offerings of this course

I believe that after this case I will be better prepared for a career in public accounting

When preparing my case I had access to all necessary resources

I feel like the case pulled together class concepts, enabling me to see the bigger picture

\section{Panel B: Case B (HealthSouth), $\mathbf{n}=\mathbf{2 8}$}

\section{Question}

The case offered an effective way to learn earnings management and compensation planning concepts ${ }^{\mathrm{a}}$

The case illustrated the interplay between tax and nontax issues

After the case, I better understand the importance of nontax issues in compensation planning

The level of difficulty in the case is appropriate for this course

I would recommend the use of this case in future offerings of this course

I believe that after this case I will be better prepared for a career in public accounting

\begin{tabular}{|c|c|c|}
\hline $\begin{array}{c}\text { Mean } \\
\text { (Std. Dev.) }\end{array}$ & $\begin{array}{c}\text { Mean } \\
\text { Difference }^{\mathbf{b}}\end{array}$ & $\begin{array}{c}\text { Lower } \\
\text { CI I }^{\mathbf{c}}\end{array}$ \\
\hline 5.50 & $1.50 * * *$ & 4.71 \\
\hline \multicolumn{3}{|l|}{$(0.97)$} \\
\hline $\begin{array}{c}5.30 \\
(1.42)\end{array}$ & $1.30 * * *$ & 4.14 \\
\hline 5.70 & $1.70 * * *$ & 4.76 \\
\hline \multicolumn{3}{|l|}{ (1.16) } \\
\hline $\begin{array}{c}5.30 \\
(1.25)\end{array}$ & $1.30 * * *$ & 4.28 \\
\hline 5.20 & $1.20 * * *$ & 4.13 \\
\hline (1.32) & & \\
\hline 4.50 & 0.50 & 3.47 \\
\hline (1.27) & & \\
\hline $\begin{array}{c}5.40 \\
(1.43)\end{array}$ & $1.40 * * *$ & 4.24 \\
\hline 5.50 & $1.50 * * *$ & 4.40 \\
\hline
\end{tabular}


TABLE 2 (continued)

Question

Mean Mean Lower (Std. Dev.)Difference ${ }^{\mathbf{b}} \mathbf{C I}^{\mathbf{c}}$ table2-03b_cont2

(1.44)

$\begin{array}{lll}5.78 & 1.78^{* * *} \quad 5.19\end{array}$

When preparing my case I had access to all necessary resources

I feel like the case pulled together class concepts, enabling me to see the bigger picture

$1.63 * * *$

Panel C: Case C (Students' Choice), $\mathbf{n}=\mathbf{2 9}$

\section{Question}

The case offered an effective way to learn tax and compensation planning concepts ${ }^{\mathrm{a}}$

The case illustrated the interplay between tax and nontax issues

After the case, I better understand the importance of nontax issues in compensation planning

The level of difficulty in the case is appropriate for this course

I would recommend the use of this case in future offerings of this course

I believe that after this case I will be better prepared for a career in public accounting

When preparing my case I had access to all necessary resources

I feel like the case pulled together class concepts, enabling me to see the bigger picture

\begin{tabular}{|c|c|c|}
\hline $\begin{array}{c}\text { Mean } \\
\text { (Std. Dev.) }\end{array}$ & $\begin{array}{c}\text { Mean } \\
\text { Difference }\end{array}$ & $\begin{array}{c}\text { Lowel } \\
\text { CI }^{\mathbf{c}}\end{array}$ \\
\hline 5.66 & $1.66^{* * *}$ & 4.67 \\
\hline (1.40) & & \\
\hline $\begin{array}{c}5.52 \\
(1.21)\end{array}$ & $1.52 * * *$ & 4.58 \\
\hline 5.55 & $1.55^{* * *}$ & 4.66 \\
\hline
\end{tabular}

5.48

$1.48 * * *$

$1.48 * * *$

$1.31 * * *$

5.90

$1.90 * * *$

*** Significant at the 0.01 level.

${ }^{\text {a }}$ Scale: 1 (strongly disagree) to 7 (strongly agree), with 4 (neutral).

${ }^{\mathrm{b}}$ Mean difference from neutral point of 4 . Positive mean differences indicate relative agreement, while negative differences indicate relative disagreement.

${ }^{\mathrm{c}}$ Denotes the lower confidence interval around the mean using a 99 percent confidence based on the stated number of observations. 


\section{Teaching and Implementation Guidance}

\section{Customizing the Case}

When incorporated into a tax course, Cases $A$ and $C$ provide students with an opportunity to incorporate a number of tax and nontax concepts typically covered in the course while creating the CEO's compensation plan for a real corporation. Whether the student is assigned Cisco Systems (Case A) or the student is allowed to choose his/her own company (Case C), the case allows students to experience the interplay between tax and managerial issues.

While the general focus of Cases $A$ and $C$ centers on tax, Case $B$ focuses on earnings management and, therefore, provides a case option appropriate for graduate accounting courses. The use of HealthSouth in Case B enables graduate accounting course students to see the potential drawbacks associated with stock and option compensation dominating the CEO's compensation mix. While compensation-oriented incentives were not the only cause for the HealthSouth fraud, students observe that the compensation benefits for stock price appreciation were so large that it is difficult to deny that they were not at least a contributing factor. The three case options make it adaptable to a number of upper-level and graduate courses, various teaching philosophies, and small or large class sizes. The case can be assigned as an individual or group assignment, providing the students with very different learning environments.

\section{General Timeline}

\section{Case A}

In a graduate corporate taxation/Scholes-Wolfson course, Case A was assigned in conjunction with a series of lectures examining both executive compensation and earnings management. Students were assigned to complete the case individually. The instructor covered the relevant material in two to three 75-minute lectures prior to the assignment of the case. Students were given about three weeks to generate the deliverables. Students required approximately eight hours to individually complete the assignment.

\section{Case B}

In a capstone graduate accounting course, this case was assigned in conjunction with the coverage of earnings management. Students were assigned to complete the cases in groups of three or four students. The instructor covered the relevant material in one 75-minute lecture prior to the assignment of the case. Students were given about two weeks to generate the deliverables. Student groups required approximately ten hours to complete the assignment.

\section{Case $C$}

Case $C$ was also assigned in a graduate corporate taxation/Scholes-Wolfson course during a different semester than Case $A$, and was also assigned in conjunction with a series of lectures examining both executive compensation and earnings management. Students were assigned to complete the case individually. The instructor covered the relevant material in two to three 75-minute

\footnotetext{
${ }^{4}$ Each of the three groups was asked seven questions related to the learning objectives; therefore, Table 1 presents the pre/post questionnaire results of 21 questions. For all 21 questions, students rated their understanding higher after the case than before the case. In spite of the relatively small sample sizes, 18 of the 21 questions had statistically significant differences, suggesting that the case was effective in meeting its learning objectives.

5 Mean student response in the third class was 4.50 , above the neutral point of 4 . The small sample size in the third class (10 students) may have contributed to the lack of statistical significance on this question.
} 
lectures prior to the assignment of the case. Students were given about three weeks to generate the deliverables. Students required approximately ten hours to individually complete the assignment.

\section{TEACHING NOTES AND STUDENT VERSION OF THE CASE}

Teaching Notes and the Student Version of the Case are available only to non-student-member subscribers to Issues in Accounting Education through the American Accounting Association's electronic publications system at http://aaapubs.org/. Non-student-member subscribers should use their usernames and passwords for entry into the system where the Teaching Notes can be reviewed and printed. The "Student Version of the Case" is available as a supplemental file that is posted with the Teaching Notes. Please do not make the Teaching Notes available to students or post them on websites.

If you are a non-student-member of AAA with a subscription to Issues in Accounting Education and have any trouble accessing this material, then please contact the AAA headquarters office at info@aaahq.org or (941) 921-7747.

\section{REFERENCES}

Scholes, M., M. Wolfson, M. Erickson, E. Maydew, and T. Shevlin. 2008. Taxes and Business Strategy: A Planning Approach. Englewood Cliffs, NJ: Prentice Hall. 
Copyright of Issues in Accounting Education is the property of American Accounting Association and its content may not be copied or emailed to multiple sites or posted to a listserv without the copyright holder's express written permission. However, users may print, download, or email articles for individual use. 